\title{
The Relationship Between Criminal Records and Job Performance: An Examination of Customer Service Representatives
}

Jakari N. Griffith

Bridgewater State University

Todd C. Harris

Bridgewater State University

Follow this and additional works at: https://scholarworks.bgsu.edu/pad

Part of the Human Resources Management Commons, Industrial and Organizational Psychology Commons, and the Other Psychology Commons

How does access to this work benefit you? Let us know!

\section{Recommended Citation}

Griffith, Jakari N. and Harris, Todd C. (2020) "The Relationship Between Criminal Records and Job Performance: An Examination of Customer Service Representatives," Personnel Assessment and Decisions: Number 6 : Iss. 3 , Article 3. DOI: https://doi.org/10.25035/pad.2020.03.003

Available at: https://scholarworks.bgsu.edu/pad/vol6/iss3/3

This Main Article is brought to you for free and open access by the Journals at ScholarWorks@BGSU. It has been accepted for inclusion in Personnel Assessment and Decisions by an authorized editor of ScholarWorks@BGSU. 


\title{
The Relationship Between Criminal Records and Job Performance: An Examination of Customer Service Representatives
}

\author{
Jakari N. Griffith ${ }^{1}$ and Todd C. Harris ${ }^{1}$
}

\author{
1. Bridgewater State University
}

ABSTRACT

\section{KEYWORDS \\ criminal record, job performance, turnover, ban-the-box}

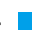

\begin{abstract}
Between 70 million and 100 million Americans-or as many as one in three-have some type of criminal record (Vallas \& Dietrich, 2014). Having even a minor criminal record often functions as a significant impediment to gainful employment and resultant economic security. This is especially problematic given that: (a) many companies now incorporate background checks within their hiring process and (b) little empirical research exists about the relationship between criminal records and job performance. Thus, this study examined the relationship between criminal records and objective performance of customer service representatives $(\mathrm{N}=627)$ in a large telecommunications firm. Our regression analyses indicate that criminal record was not a predictor of job performance.
\end{abstract}

To date, overall research findings suggest employers tend to view applicants having criminal records with distrust, believing they are less reliable and more likely to relate to others poorly (Ali et al., 2017; Holzer et al., 2004; Kleiman \& Kass, 2014; Pager, 2003; Young \& Powell, 2015). This characterization has had profoundly negative impacts on reported levels of employment among those with criminal records. According to research sponsored by the Department of Justice, criminal records reduced an applicant's employment chances by nearly half (Pager \& Western, 2009). Other studies have shown that despite being equally qualified, formerly incarcerated candidates are less than half as likely to receive job offers when compared to those who have not been incarcerated (Pager, 2003). The stigma associated with criminal records in the context of the hiring, therefore, strongly contributes to an organization's reluctance to engage with applicants who possess these unfavorable characteristics as evidenced in the significantly high unemployment rates, which are approximated at about 50\% (Nally et al., 2011).

Although scholars have spent considerable time exploring the various ways in which criminal records impact hiring, barring only two notable exceptions (Lundquist et al., 2018; Minor et al., 2018), there is a significant lack of empirical evidence documenting what happens after these individuals are employed. For example, Griffith et al.'s (2019) systematic review of 58 research studies examining the relationship between criminal records and employment confirms that the preponderance of available research has almost exclusively focused on the initial stages of the employment relationship (selection and hiring) but fails to include the vast domain of postemployment job performance behavior. Thus, it is unclear how criminal records relate to job performance, specifically the dimensions of task performance or other workplace behaviors (Sackett, 2002).

Further complicating our understanding of this relationship are the various studies showing that criminal records correlate with lower than average intelligence scores (Neisser et al., 1996) and higher levels of negative affectivity (Giordano et al., 2007). One the one hand, because these variables have also been shown to share a negative relationship with a number of valued employee behaviors such as learning motivation and non-deviant conduct (Colquitt et al., 2000; Lyons et al., 2016), it could be argued that these individuals should come into organizations and perform more poorly than their counterparts without criminal record. On the other hand, it could also be argued that stigma attached to criminal records produces a compensatory job performance effect by elevating levels of identity-related motivation. Indeed, recent qualitative investigations on the effects of incarceration on employment have posited such an effect. Anazoda et al. (2019) found that defying performance expectations, defined as an "active attempt to dis-

\footnotetext{
Corresponding author:

Jakari N. Griffith

Email: jgriffith@bridgew.edu
} 
prove common stereotypes associated with [criminal history]...by increasing effort or displaying a strong work ethic" (p. 569), served as a prominent strategy used to cope with a negative criminal identity. Palmer and Christian (2019) qualitative investigation also found that incarcerated individuals viewed employment as an opportunity to showcase their strong work ethic and to show that, despite having a criminal record, they could assume greater responsibility. Research, thus, appears to be converging on the notion that the presumed negative connections between criminal records and work performance may be overly deterministic (Young \& Ryan, 2019). However, there is an insufficient number of empirical research studies available to evaluate the veracity of these claims.

The current investigation expands on these studies by explicitly investigating the relationship between criminal records and task performance. This research aims to provide valuable evidence that may help to better inform future theory building and policy development.

\section{Criminal Records Stigma and Social Identity Theory}

According to stigma theory, criminal records reflect something unusual or bad about the moral status of the individual, as such conduct generally falls outside of acceptable social-normative bounds (Goffman, 1963; Major \& O'Brien, 2005). Negative attitudes and stereotypes directed toward an applicant on the basis of stigmas can, therefore, significantly reduce employment opportunities for ex-offenders. For instance, in a survey examining employer willingness to hire ex-offenders, Holzer et al. (2004) found that "over 40 percent of employers... would 'probably' or 'definitely' not be willing to hire an applicant with a criminal record for a job not requiring a college degree" (p. 41). Subtler stigmatization effects can be found in the actual applicant interviewing process. Smith (2014) noted that, "an employer who has decided to reject an applicant because of her criminal history may use information uncovered during the interview as a pretextual justification for the decision to deny the applicant the position" (p. 217). Young and Powell (2015) posited that ex-offenders can often be viewed from a lens of coldness and incompetence, and Ali et al. (2017) suggested applicants with criminal records are routinely stigmatized if explanations of previous offenses are not accompanied by an apology or remorse.

The instances described above suggest stigma can form the basis of employment evaluation (Ragins, 2008). However, stigma theory does not provide an adequate explanation as to how applicants respond to the effects of negative stigma. As a complementary explanatory process, social identity theory argues that persons with a perceived negative identity (i.e., criminal backgrounds) will seek out positive social identities by becoming members of or attempting to belong to a valued group (Tajfel \& Turner, 2004), a process that is generally accomplished by reproducing behaviors and attitudes that mimic prototypical norms of the group to which they are seeking acceptance. Applied to ex-offenders, the theory suggests employees with criminal records might attempt to generate favorable appraisals of their potential as group members by performing at levels that match or exceed the performance levels of peers, in hopes to accomplish the following: (a) distance themselves from their previously devalued social identity (Branscombe et al., 1999), (b) and to facilitate group inclusion by appearing more like other group members on a shared attribute of comparison (performance; Dovidio et al., 2010; Ellemers et al., 2002). Indeed, Griffith and Young's (2017) qualitative investigation of managerial perceptions of ex-offenders provides anecdotal support for this assertion, as their research showed that managers believe ex-offenders will "work harder [than their peers] to keep their employment. They are engaged. They want to do well. They want to prove they can do it [the tasks well]" (p. 512). From this perspective, work performance could be an important mechanism by which ex-offenders attempt to either self-categorize into valued groups and/or attempt to manage a tainted social identity.

One challenge underlying the lack of research on this topic, however, is the fact performance data on ex-offenders are extremely difficult to obtain. Rarely do organizations collect data pertaining to criminal records history, and if these data are collected, they are usually handled entirely by a third party (Minor et al., 2018). Studies on this topic are so rare that searches of typical academic and management scientific databases (e.g., Science.gov, PsycINFO, JSTOR, Google Scholar, etc.) yield only two studies on the subject (Lundquist et al., 2018; Minor et al., 2018). Thus, it is clear that research needs to further examine the relationship between criminal records and job performance. Therefore, we posit that criminal records stigmatize aspects of an employee's character and thus cause him or her to positively alter their work behaviors in order to overcome what is believed to be an identity-defining limitation: having a criminal record.

\section{METHOD}

\section{Sample and Procedure}

The study sample includes telephone call center representatives from a Fortune 500 media company located in the United States. Due to a limitation in data gathering protocol within the organization, the employer was unable to provide any data regarding employee age. Furthermore, educational attainment levels were missing for some of the participants in the study sample and were thus removed. In addition, because there were few if any minorities (nonWhite workers) with criminal convictions represented in the data set, our sample frame focuses exclusively on performance assessments of White workers who are female, a population that has traditionally been overrepresented in 
customer service representative roles in the United States (http://datausa.io). Finally, the employer provided all data on the condition of anonymity and under the guise that the analysis of such data might provide research insight to inform practitioner policies and decisions related to hiring individuals with criminal offenses.

\section{Measures}

Demographic information. The employer provided basic demographic information including race and sex. Additionally, provided data included criminal conviction status.

Performance index variable. Because the company-provided data assessed several distinct features of task performance, we developed an index variable by collapsing the following four performance indicators together: (a) quality assurance: a measure of the overall satisfaction with the service call experience; (b) transfer rate: a measure for the number of calls an agent has to transfer to someone else to complete; (c) call back rates: a measure for the number of times a customer called back; and (d) claims: a measure for whether a claim was filed by a customer. A principal component factor analysis was performed, which yielded single factor (see Table 1), thus leading to the calculation of a single performance variable based on mean item scores of each scale (higher numbers are representative of better performance). Cronbach's alpha shows that the resulting index variable falls just short of the threshold for internal reliability ( $\alpha=51$; Nunally, 1978). However, scholars suggest that when the number of indicators is very small, as is the case here, reliability tends to be significantly underestimated (Lance et al., 2006; Tavakol \& Dennick, 2011). At the same time, alpha may be less consequential for purposes of this study because we are not measuring a theoretical concept as an operationalized construct (Cortina, 1993; Green et al., 1977). We are, instead, combining various company-generated performance metrics into a single variable in order to improve the interpretability of the results.

Statistical analysis. To examine the extent to which criminal conviction status differences existed in the study variables of interest, we conducted a liner regression analysis using conviction status and tenure as the independent variables, and task performance as the dependent variable. We used SPSS 26 statistical software for all analyses.

\section{RESULTS}

\section{Descriptive Statistics}

The sample in this study includes 627 telephone call center representatives who were both White and female, and whose tenure with the organization averaged 19 months.

\section{Correlational Statistics}

This study found a negative relationship between tenure and criminal records $(r=-.08, p<.05)$, and a positive relationship between tenure and performance $(r=.10, p$ $<.05$ ). Meanwhile, no statistically significant relationship was shown between criminal records and performance. Table 2 summarizes the descriptive statistics and correlational results.

TABLE 1.

Results of Factor Analysis for the Performance Index Variable

\begin{tabular}{lcccc}
\hline Variable & $M$ & $S D$ & Factor loading & \% of variance \\
\hline Quality assurance & -.052 & .968 & .383 & 40.54 \\
Call transfer rate & -.030 & .985 & .383 & 24.16 \\
Callback rate & -.049 & .950 & .329 & 19.75 \\
Claims rate & -.029 & 1.01 & .463 & 15.53 \\
\hline
\end{tabular}

Note. Extraction method: principal component analysis. Alpha reliability: .95.

TABLE 2.

Descriptive Statistics and Variable Correlation

\begin{tabular}{lccccc}
\hline Variable & $M$ & $S D$ & 1 & 2 & 3 \\
\hline Conviction & .40 & .49 & -- & -- & \\
Tenure (months) & 19.7 & 19.5 & $-.08^{*}$ & -- & \\
Performance & -0.23 & .67 & -.07 & $.10^{*}$ & -- \\
\hline
\end{tabular}

Note. $N=627 . * p<.05$. Correlations are found on the diagonal.

The conviction variable was coded 1 for conviction and 0 for no conviction. 
TABLE 3.

Criminal Records and Tenure Regressed on Performance

\begin{tabular}{lccccc}
\hline Variable & $B$ & $S E$ & $\beta$ & $t$ & $p$ \\
\hline Constant & -.053 & .045 & -- & -1.193 & .233 \\
Record & -.086 & .054 & -.063 & -1.577 & .115 \\
Tenure & .003 & .001 & .096 & 2.406 & $.016^{*}$ \\
\hline
\end{tabular}

Note. ${ }^{*} p<.05$.

\section{Regression Analyses}

A linear regression model with two predictors (conviction and tenure) were regressed on performance, producing an $R^{2}=.014, F(2,624)=4.47, p<.012$. As evidenced in Table 3, criminal records did not contribute to the multiple regression model. However, time with the organization (tenure) had a significant positive regression weight, indicating that more years spent in a customer service role correspond to higher levels of performance after controlling for the other variable in the model. Based on these findings, we establish that criminal records are a poor predictor of job performance behavior, but other factors such as tenure may have a potentially positive impact on work outcomes.

\section{DISCUSSION}

To date, there has been a little research examining whether criminal history is a valid predictor of objective job performance-in this case, task performance. By focusing on task-specific behaviors at work, we aim to deepen our understanding of the relationship shared between criminal history and job performance. Based on the results of this study, we find the relationship between criminal records and performance is virtually nonexistent.

Although it is tempting to view criminal history as a proxy measure for reliability or conscientious, both of which have clear relationship with performance, our results seem to challenge the view that criminal records have any connection to job performance. What can be gleaned from our analysis is that employees may have actively regulated their behavior to meet or exceed job demands, at least at the outset of employment. However, that performance improves over time could indicate employees have gained mastery over key performance behaviors in effort to improve overall job opportunities. Because so much of organizational life of is governed by explicit performance standards and norms, it appears plausible that individuals with a stigmatized identity may readily emulate group performance norms as a means to secure acceptance and to differentiate themselves from a past negative identity, which in turn, increases the number of potential career opportunities. Indeed, there is a need for additional research in this area.
First, recognizing that the two primary goals of any personnel selection system are to: (1) hire qualified applicants for the job, and (2) to do so in a fair, non-biased way, it appears there is no immediate evidence that the inclusion of criminal record contributes meaningfully to either of those goals in this specific study. Second, organizations may want to adopt policies where criminal history information is considered only after assessments of an employee's qualifications or not considered at all. The background checks that many organizations currently employ can uncover a much broader array of misconduct, including arrests for relatively minor crimes that never result in formal charges. The severity, type, and timing of various offenses will also likely play a significant role in an employer's staffing decisions. Furthermore, there is no knowledge of how criminal records might function to create glass ceilings after an individual is hired. Thus, one critical step in addressing the needs of ex-offenders is to examine the existing assumptions about the role and value of criminal history information in the employment selection process. This study is one of the first to begin dismantling these biases.

\section{Study Limitations}

Although the sample used in this study was predominately White and predominately female, it can be argued that these results provide a clear and unambiguous assessment of the relationships posed in this study. Still in all, gender might implicate different social identity motives in the context of gendered perceptions of criminality.

In addition, because these data were collected with the aid of a third party, little is known about the severity of the criminal offenses or the conviction statuses of employees. Although we can assume that none of the offenses were job related, one key limitation is that we cannot determine if there were any differences between those with felony criminal records and those with misdemeanors. This might be an important or meaningful distinction given that those with felony records often face stiffer penalties in terms of sentencing and thus may have had more years away from work than those convicted of misdemeanors. Unfortunately. this study was unable to capture any of these specific nuances. Future research must take this variable into consideration. 


\section{REFERENCES}

Ali, A. A., Lyons, B. J., \& Ryan, A. M. (2017). Managing a perilous stigma: Ex-offenders' use of reparative impression management tactics in hiring contexts. Journal of Applied Psychology, 102(9), 1271-1285.

Anazodo, K. S., Ricciardelli, R., \& Chan, C. (2019). Employment after incarceration: Managing a socially stigmatized identity. Equality, Diversity and Inclusion: An International Journal, 38(5), 564-582.

Branscombe, N. R., Ellemers, N., Spears, R., \& Doosje, B. (1999). The context and content of social identity threat. In N. Ellemers, R. Spears, \& B. Doosje (Eds.), Social identity: Context, commitment, content (pp. 35-58). Blackwell Science.

Colquitt, J. A., LePine, J. A., \& Noe, R. A. (2000). Toward an integrative theory of training motivation: a meta-analytic path analysis of 20 years of research. Journal of Applied Psychology, 85(5), 678-707.

Cortina, J. M. (1993). What is coefficient alpha? An examination of theory and applications. Journal of Applied Psychology, 78(1), 98-104.

Dovidio, J. F., Gaertner, S. L., Shnabel, N., Saguy, T., \& Johnson, J. (2010). Recategorization and prosocial behavior: Common in-group identity and a dual identity. In S. Stürmer \& M. Snyder (Eds.), The psychology of prosocial behavior: Group processes, intergroup relations, and helping (pp. 191-207). Wiley-Blackwell.

Ellemers, N., Spears, R., \& Doosje, B. (2002). Self and social identity. Annual Review of Psychology, 53, 161-186.

Giordano, P. C., Schroeder, R. D., \& Cernkovich, S. A. (2007). Emotions and crime over the life course: A neo-Meadian perspective on criminal continuity and change. American Journal of Sociology, 112(6), 1603-1661.

Goffman, E. (1963). Stigma: Notes on the management of spoiled identity. 1 st ed. Prentice-Hall.

Green, S. B., Lissitz, R. W., \& Mulaik, S. A. (1977). Limitations of coefficient alpha as an index of test unidimensionality. Educational and Psychological Measurement, 37(4), 827-838.

Griffith, J. N., \& Young, N. C. J. (2017). Hiring ex-offenders? The case of ban the box. Equality, Diversity and Inclusion: An International Journal, 36(6), 501-518.

Griffith, J. N., Rade, C. B., \& Anazodo, K. S. (2019). Criminal history and employment: an interdisciplinary literature synthesis. Equality, Diversity and Inclusion: An International Journal, 38(5), 505-528.

Holzer, H.J., Raphael, S., \& Stoll, M.A. (2004). How willing are employers to hire ex- offenders? Focus, 23(2), 40-43.

Kleiman, L. S., \& Kass, D. (2014). Employer liability for hiring and retaining unfit workers: How employers can minimize their risks. Employment Relations Today, 41(2), 33-41.

Lance, C. E., Butts, M. M., \& Michels, L. C. (2006). The sources of four commonly reported cutoff criteria: What did they really say? Organizational Research Methods, 9(2), 202-220.

Lundquist, J.H., Pager, D. \& Strader, E. (2018). Does a criminal past predict worker performance? Evidence from America's largest employer. Social Forces, 96(3), 1039-1068.

Lyons, B. D., Hoffman, B. J., Bommer, W. H., Kennedy, C. L., \& Hetrick, A. L. (2016). Off-duty deviance: Organizational policies and evidence for two prevention strategies. Journal of Ap- plied Psychology, 101(4), 463-483.

Major, B., \& O'brien, L. T. (2005). The social psychology of stigma. Annual Review Psychology, 56, 393-421.

Minor, D., Persico, N. \& Weiss, D. M. (2018). Criminal background and job performance. Retrieved from SSRN: https://ssrn. com/abstract $=2851951$.

Nally, J. M., Lockwood, S. R., \& Ho, T. (2011). Employment of ex-offenders during the recession. Journal of Correctional Education, 62(2), 117-131.

Neisser, U., Boodoo, G., Bouchard Jr, T. J., Boykin, A. W., Brody, N., Ceci, S. J., Halpern, D. F., Loehlin, J. C., Perloff, R., Sternberg, R. J., \& Urbina, S. (1996). Intelligence: Knowns and unknowns. American Psychologist, 51(2), 77-101.

Nunnally, J. C. (1978). Assessment of reliability. In Psychometric theory (2nd ed.). McGraw-Hill.

Pager, D. (2003). The mark of a criminal record. American Journal of Sociology, 108(5), 937-975.

Pager, D., \& Western, B. (2009). Investigating prisoner reentry: The impact of conviction status on the employment prospects of young men. Washington, DC National Institute of Justice.

Palmer, C., \& Christian, J. (2019). Work matters: formerly incarcerated men's resiliency in reentry. Equality, Diversity and Inclusion: An International Journal, 38(5), 583-598.

Ragins, B. R. (2008). Disclosure disconnects: Antecedents and consequences of disclosing invisible stigmas across life domains. Academy of Management Review, 33(1), 194-215.

Sackett, P. R. (2002). The structure of counterproductive work behaviors: Dimensionality and relationships with facets of job performance. International Journal of Selection and Assessment, 10(1/2), 5-11.

Smith, J.J. (2014). Banning the box but keeping the discrimination: Disparate impact and employers' overreliance on criminal background checks. Harvard Civil Rights and Civil Liberties Law Review, 49, 197-228.

Tavakol, M., \& Dennick, R. (2011). Making sense of Cronbach's alpha. International Journal of Medical Education, 2, 53-55.

Tajfel, H., \& Turner, J. C. (2004). The Social Identity Theory of Intergroup Behavior. In J. T. Jost \& J.Sidanius (Eds.), Key readings in social psychology. Political psychology: Key readings (pp. 276-293). Psychology Press.

Vallas, R., \& Dietrich, S. (2014). One strike and you're out: How we can eliminate barriers to economic security and mobility for people with criminal records. Center for American Progress. https://cdn.americanprogress.org/wp-content/ uploads/2014/12/VallasCriminalRecordsReport.pdf

Young, N. C. J., \& Powell, G. N. (2015). Hiring ex-offenders: A theoretical model. Human Resource Management Review, 25(3), 298-312.

Young, N. C. J., \& Ryan, A. M. (2019). Criminal history and the workplace: A pathway forward. Equality, Diversity and Inclusion: An International Journal, 38(5), 494-504.

\section{RECEIVED 06/01/18 ACCEPTED 03/03/20}

